\title{
Autologous T-cell therapy based on a lentiviral vector expressing long antisense RNA targeted against HIV-1 env gene influences HIV replication and evolution in vivo
}

\author{
Alexander Pasternak ${ }^{1 *}$, Nikolay Korokhov², Ben Berkhout ${ }^{1}$, Vladimir Lukashov ${ }^{1}$, Laurent Humeau ${ }^{2}$ \\ From Frontiers of Retrovirology: Complex retroviruses, retroelements and their hosts \\ Cambridge, UK. 16-18 September 2013
}

\section{Background}

We report the results of a Phase II clinical trial of VRX496, an HIV-based vector encoding a 937-nt long antisense (AS) RNA targeting the gp120 coding region of HIV-1 env gene [1-3].

\section{Materials and methods}

Autologous $\mathrm{CD} 4^{+} \mathrm{T}$ lymphocytes from HIV-infected subjects were genetically modified ex vivo with the vector, expanded, and 10-80 billion vector-modified cells were reinfused into patients. Longitudinal effects of the therapy on HIV-1 env evolution were analyzed in 17 subjects sampled both pre-infusion and monthly postinfusion for 6 to 12 months. Plasma-derived viral RNA from 144 samples was amplified, cloned, and the fulllength gp120 coding region was sequenced in 8-10 clones for each sample.

\section{Results}

Two AS-related factors: (a) sequence similarity of the AS RNA with the targeted HIV transcripts at baseline, and (b) persistence of the infused vector-modified cells during the follow-up period, independently and cooperatively influenced the following parameters: (i) pairwise genetic distances of the gp120 conserved region sequences in the post-infusion samples to the corresponding pre-infusion samples, (ii) change in viral diversity from baseline, (iii) genetic distances of the post-infusion viral quasispecies to the most recent common ancestral sequence (MRCA)

${ }^{1}$ Academic Medical Center of the University of Amsterdam, Department of Medical Microbiology, Amsterdam, The Netherlands

Full list of author information is available at the end of the article of all patient's viral sequences, relative to the MRCA distances of pre-infusion viruses, and (iv) change of HIV-1 plasma RNA load from baseline $(P<0.005$ for all parameters). The effects of AS vector on virus evolution were stronger for the AS-targeted region of gp120 than for the untargeted region. The degree of virus evolution from the pre-infusion to the post-infusion quasispecies (relative MRCA distances) negatively correlated with virus replicative fitness, assessed ex vivo by growth competition assay.

\section{Conclusions}

The same AS-related factors were associated with accelerated virus evolution and with the relative decrease in plasma viral load, suggesting that selective pressure exerted by the AS causes directional virus evolution, presumably towards escape, which is associated with the fitness loss.

\section{Authors' details}

'Academic Medical Center of the University of Amsterdam, Department of Medical Microbiology, Amsterdam, The Netherlands. ${ }^{2}$ VIRxSYS Corporation, Gaithersburg, USA.

Published: 19 September 2013

\section{References}

1. Levine BL, Humeau LM, Boyer J, MacGregor RR, Rebello T, Lu X, et al: Gene transfer in humans using a conditionally replicating lentiviral vector. Proc Natl Acad Sci U S A 2006, 103:17372-17377.

2. Humeau LM, Binder GK, Lu X, Slepushkin V, Merling R, Echeagaray P, et al: Efficient lentiviral vector-mediated control of HIV-1 replication in CD4 lymphocytes from diverse HIV+ infected patients grouped according to CD4 count and viral load. Mol Ther 2004, 9:902-913.

3. Lu X, Yu Q, Binder GK, Chen Z, Slepushkina T, Rossi J, et al: Antisensemediated inhibition of human immunodeficiency virus (HIV) 
replication by use of an HIV type 1-based vector results in severely attenuated mutants incapable of developing resistance. J Virol 2004 78:7079-7088

doi:10.1186/1742-4690-10-S1-046

Cite this article as: Pasternak et al: Autologous T-cell therapy based on a lentiviral vector expressing long antisense RNA targeted against HIV-1 env gene influences HIV replication and evolution in vivo. Retrovirology 2013 10(Suppl 1):046.

Submit your next manuscript to BioMed Central and take full advantage of:

- Convenient online submission

- Thorough peer review

- No space constraints or color figure charges

- Immediate publication on acceptance

- Inclusion in PubMed, CAS, Scopus and Google Scholar

- Research which is freely available for redistribution

Submit your manuscript at www.biomedcentral.com/submit
C) Biomed Central 